\title{
Characterization of intracytoplasmic prokaryote infections in Dreissena sp. (Bivalvia: Dreissenidae)
}

\author{
Daniel P. Molloy ${ }^{1, *}{ }^{,}$Laure Giamberini ${ }^{2}$, J. Frank Morado ${ }^{3}$, Sergei I. Fokin ${ }^{4}$, \\ Franck Laruelle ${ }^{5}$

\begin{abstract}
${ }^{1}$ New York State Museum, The State Education Department, Cultural Education Center, Albany, New York 12230, USA
${ }^{2}$ Equipe de Production des Ecosystèmes et Ecotoxicologie, Laboratoire EBSE, Université de Metz, Campus Bridoux, rue du Gal Délestraint, 57070 Metz Cedex, France

${ }^{3}$ National Oceanic \& Atmospheric Administration, National Marine Fisheries Service, Alaska Fisheries Science Center, Resource Assessment \& Conservation Engineering Division, 7600 Sand Point Way NE, Seattle, Washington 98115-0070, USA

${ }^{4}$ Biological Research Institute, St. Petersburg State University, St. Petersburg 198904, Russia

${ }^{5}$ UMR CNRS 6539, Institut Universitaire Européen de la Mer, UBO, Place Nicolas Copernic, Technopôle Brest-Iroise, 29280 Plouzané, France
\end{abstract}

\begin{abstract}
This study characterizes intracytoplasmic infections with prokaryote microorganisms in Dreissena sp. (near Dreissena polymorpha) from northeastern Greece and represents the first report of such infections in freshwater bivalves. Light microscope observations of stained tissues revealed basophilic, cytoplasmic inclusion bodies in $87.5 \%(28 / 32)$ of the mussels sectioned. Inclusions in epithelial cells and connective tissues were noted, respectively, in 34.4 and $71.9 \%$ of the sample, with 5 mussels $(15.6 \%)$ having both tissue types infected. Epithelial cell infections were observed in histological sections only in digestive gland tubules and ducts; within tubules, inclusions were present more often in secretory than digestive cells. Connective tissue infections, however, were systemic; among the 32 mussels sectioned, inclusions were found in the gills $(65.6 \%)$, foot $(12.5 \%)$, mantle $(9.4 \%)$, labial palps $(6.3 \%)$, digestive gland $(6.3 \%)$, stomach $(6.3 \%)$, and gonads (3.1\%). Cytoplasmic inclusions (maximum dimension, $138 \mu \mathrm{m}$ ) were prominent enough in the gills to be visible in $17.0 \%$ of the 247 mussels dissected. Ultrastructurally, prokaryote cells in gill connective tissues were clearly characteristic of Chlamydiales-like organisms, with each intracytoplasmic inclusion containing a loosely packed mixture of elementary, reticulate, intermediate bodies, and blebs. Prokaryote colonies in digestive gland epithelial cells exclusively contained 1 of 4 morphological cell types and were considered Rickettsiales-like. Hexagonal, virus-like particles were present in the cytoplasm of the largest of these Rickettsiales-like prokaryotes. Although host stress was evident from localized cell necrosis and dense hemocyte infiltration, overall infection was fairly benign, with no major, adverse impact on body condition evident among sectioned or dissected mussels. A possible negative effect was partial constriction of gill water tubes, but at the infection intensity observed (typical range 1 to 7 inclusion bodies per section), significant interference with respiration and other metabolic functions of the gills was highly unlikely.
\end{abstract}

KEY WORDS: Zebra mussels · Intracytoplasmic prokaryote - Epithelium • Connective tissue • Virus-like particles $\cdot$ Rickettsiales-like $\cdot$ Chlamydiales-like

\section{INTRODUCTION}

The invasion and spread of zebra mussels Dreissena polymorpha and quagga mussels Dreissena bugensis

*E-mail:dmolloy@mail.nysed.gov throughout North American freshwaters since the mid1980s has had significant adverse economic and ecological impacts. As major macrofoulers of raw-water conduits within infrastructures, they have caused damage and increased operating expenses totaling hundreds of millions of dollars (O'Neill 1996, 1997). Envi-

으 Inter-Research 2001 
ronmental impacts in North America (Strayer 1999) are similar to European experiences (Karatayev et al. 1997), including decreased phytoplankton productivity (Fahnenstiel et al. 1995), increased native bivalve mortality (Schloesser et al. 1996), and restructured benthic communities (Stewart et al. 1998).

After introduction into a waterbody, population growth of Dreissena spp. can be explosive because of their life history traits of high fecundity, high growth rate, and tolerance of a range of environmental conditions. The absence of their Eurasian natural enemy complex of predators, parasites, and benthic competitors has also contributed to their rapid population growth in North America, altough to what degree is open to debate. Molloy et al. (1997) suggested that among these 3 natural enemy groups, research on Dreissena's parasites had received the least attention. This information gap is currently being addressed by a network of over a dozen scientists from the former Soviet Union, Europe, and North America as a project of the International Research Consortium on Molluscan Symbionts (IRCOMS; http//www.nysm.nysed.gov/ biology/ircoms/bio_ircoms.html). In this IRCOMS project, initial focus is on developing a database characterizing the systematics, biology, ecology, and distribution of Dreissena's parasites, as well as other symbiotic organisms encountered within these mussels (Molloy et al. 1996, Burlakova et al. 1998, Laruelle et al. 1999, Karatayev et al. 2000a,b, Laruelle et al. 2001). These data on parasites will help define the role that infectious diseases play in the population dynamics of Dreissena spp. and to what degree the relative absence of parasites in North American Dreissena populations (Toews et al. 1993, Camp et al. 1999) aids their successful colonization of waterbodies on this continent. This database may also enhance determination of whether any of Dreissena's parasites could be used as biological control agents (Molloy 1998).

The present study characterizes infection by intracytoplasmic prokaryote microorganisms (i.e., with no membrane-bound nucleus) observed in a Dreissena sp. in northeastern Greece. Prokaryotes have frequently been recorded as intracytoplasmic parasites of marine bivalves (reviewed in Bower et al. 1994, Fryer \& Lannan 1994), but this is the first report from freshwater bivalves. We present evidence that this population of zebra mussels was infected by at least 2 prokaryote species, 1 of which was hyperinfected with virus-like particles.

\section{MATERIALS AND METHODS}

Dreissena sp. were sampled from Lake Volvi, Greece $\left(40^{\circ} 37^{\prime} \mathrm{N}, 23^{\circ} 21^{\prime} \mathrm{E}\right)$ at a depth of $4 \mathrm{~m}$ on October 27 ,
1995, and shipped live overnight under refrigerated conditions to a temporary field laboratory in Seillans, France. All mussels possessed uniform shell morphology, including a flat ventral surface, and thus resembled D. polymorpha. Their species determination, however, is still undergoing analysis since their valves formed an unusually high dorsal keel that is uncharacteristic for this species (A. Y. Karatayev pers. comm.).

Mussels were examined for endosymbionts using various techniques, including immediate dissection of 247 specimens and fixation of others for subsequent histological and ultrastructural analyses at IRCOMS member laboratories. Only data on the intracytoplasmic prokaryote infections observed are presented herein. Information on other endosymbionts within this population will be published separately.

Dissections. Live mussels were sorted into $5 \mathrm{~mm}$ length size classes, and their tissues examined by dissection for gross signs of disease using a stereomicroscope $(\leq 70 \times)$. If parasitism was suspected (e.g., abnormal size, shape, and/or color of an organ), their tissues were further inspected using a phase contrast compound microscope $(\leq 1000 \times)$. In addition, small pieces of gill and digestive gland tissues were excised from other live mussels and fixed in $2.5 \%$ glutaraldehyde buffered in sodium cacodylate for subsequent ultrastructural analysis (protocol below).

Histological analysis. Thirty-two randomly chosen mussels were fixed in $10 \%$ neutral buffered formalin, dehydrated in a graded series of alcohols and toluene, and embedded in paraffin. Approximately 4 serial, oblique-longitudinal sections (5 $\mu \mathrm{m}$ thick) were cut per mussel and stained with hematoxylin and eosin (H\&E) and examined by light microscopy $(\leq 1000 \times)$. To further characterize suspected prokaryote colonies, additional sections were cut from selected mussels and processed for Giemsa, Ordway-Macchiavello, and Brown-Brenn Gram staining (Humason 1979).

Ultrastructural analysis. Some paraffin blocks with suspected prokaryote colonies were deparaffinized following Meyers (1981), and small pieces of deparaffinized tissues immersed in $2 \%$ glutaraldehyde (Grade I, Sigma Chemical Co.) in $0.025 \mathrm{M}$ sodium cacodylate buffer ( $\mathrm{pH}$ 7.4) for $90 \mathrm{~min}$ at $4^{\circ} \mathrm{C}$. These deparaffinized tissues and small pieces of tissue fixed in glutaraldehyde during dissections, were rinsed in buffer solution $(0.05 \mathrm{M})$ and post-fixed with $1 \%$ osmium tetroxide (Sigma) buffered with sodium cacodylate. After dehydration through graded alcohols, tissues were embedded in Epon-Araldite (Sigma). Ultra-thin sections (60 to $80 \mathrm{~nm}$ ), cut with a diamond knife on a LKB Ultratom V ultramicrotome, were placed on copper grids and stained with uranyl acetate and lead citrate. Sections were examined with a Jeol CX100 (80 kV) transmission electron microscope (TEM). 


\section{RESULTS}

\section{Dissections}

Translucent, round-to-oval inclusions were visible within the gills of $17.0 \%(42 / 247)$ of all dissected mussels and in $28.6 \%(42 / 147)$ of those $\geq 10 \mathrm{~mm}$ in length (Fig. 1, Table 1). Although some inclusions measured up to $138 \mu \mathrm{m}$ in maximum dimension, most were $<60 \mu \mathrm{m}$. Such large inclusions were not noticeable in any other organs during dissection. Phase contrast examination of a smear of the contents of some of these inclusions revealed fine, homogeneous material within; the levels of magnification $(1000 \times)$ and resolution were insufficient to discern the presence of microorganisms.

\section{Histological observations}

Prevalence

Light microscope observations of H\&E-stained tissues revealed basophilic, cytoplasmic inclusion bodies typical of prokaryote infections (Bower et al. 1994) in $87.5 \%$ $(28 / 32)$ of the mussels. Inclusions in epithelial cells and connective tissues were noted, respectively, in 34.4 and $71.9 \%$ of the sample, with 5 mussels $(15.6 \%)$ having both tissue types infected. Epithelial cell infections were observed only in digestive gland tubules and ducts; within tubules, inclusions were present more often in secretory than digestive cells. Connective tissue infections, however, were systemic; among the 32 mussels sectioned, inclusions were found in the gills (65.6\%), foot $(12.5 \%)$, mantle $(9.4 \%)$, labial palps $(6.3 \%)$, digestive gland $(6.3 \%)$, stomach $(6.3 \%)$, and gonads $(3.1 \%)$.

\section{Intensity}

Most infected mussels had 1 to 7 inclusions per section, but a few mussels had 12 to 30 inclusions per section in the digestive gland alone. Highest infection intensities

Table 1. Percentage of Dreissena sp. with inclusion bodies visible in gills during dissection $(\leq 70 \times)$

\begin{tabular}{|lcc|}
\hline $\begin{array}{l}\text { Size class } \\
\text { length }(\mathrm{L})(\mathrm{mm})\end{array}$ & $\begin{array}{c}\text { No. } \\
\text { dissected }\end{array}$ & $\begin{array}{c}\text { Percentage with } \\
\text { visible inclusions }\end{array}$ \\
\hline $0<\mathrm{L}<5$ & 50 & 0.0 \\
$5 \leq \mathrm{L}<10$ & 50 & 0.0 \\
$10 \leq \mathrm{L}<15$ & 41 & 34.1 \\
$15 \leq \mathrm{L}<20$ & 53 & 24.5 \\
$20 \leq \mathrm{L}<25$ & 50 & 30.0 \\
$25 \leq \mathrm{L}<30$ & 3 & 0.0 \\
Total $(0<\mathrm{L}<30)$ & 247 & 17.0 \\
\hline
\end{tabular}

were recorded in 2 mussels which had, respectively, $>90$ and >150 inclusions per digestive gland section, including $\geq 3$ inclusions in the same tubule. Among mussels which had concurrent gill and digestive gland infections (5 of 28 infected mussels), the highest infection intensity per section was $>50$ inclusions in the gill and $>20$ inclusions in the digestive gland.

\section{Cytoplasmic inclusion bodies}

Inclusion bodies contained Gram-negative prokaryotes (i.e., red colonies with Brown-Brenn stain) and were sometimes surrounded by a clear zone in both connective tissue (Fig. 2) and epithelial cells (Fig. 3). Inclusion bodies were usually spherical (diameters ranging from 5 to $25 \mu \mathrm{m}$ ) in digestive gland epithelial cells, and their texture was finely granular (Fig. 3), but occasionally coarsely granular (Fig. 4). In contrast, inclusion bodies in gill connective tissues (Figs. 2, 5 \& 6) appeared round (diameter range, 13 to $67 \mu \mathrm{m}$ ) to oval (maximum length $\times$ width, $75 \times 42 \mu \mathrm{m}$ ), and their texture was uniformly finely granular, never coarse.

\section{Histopathology}

Host response was observed in Dreissena sp. tissues only in intense infections. In such cases, connective tissues in the digestive gland, the mantle, and the gills exhibited cell necrosis. Additionally, connective tissues in the digestive gland, gills, and mantle were infiltrated with numerous hemocytes, but only in regions containing relatively numerous inclusions (Fig. 5). Inclusions in gill connective tissues were also observed to partially constrict water tubes (Fig. 6).

\section{Ultrastructural observations}

Gill connective tissue

TEM observations confirmed that the cytoplasmic inclusion bodies observed histologically in cells of the gill connective tissue were vacuoles containing colonies of prokaryote cells (Fig. 7). Prokaryote cell morphologies were clearly characteristic of Chlamydiales-like organisms (Figs. 7 to 9), with each vacuole containing a loosely packed mixture of elementary bodies (i.e., nonmultiplying cells specialized for transmission), reticulate bodies (i.e., initial, noninfectious forms that specialize in intracellular multiplication and elementary body production), and their intermediate forms (i.e., bodies undergoing nucleoid condensation). Vacuoles did not appear to be host membrane-limited, but rather surrounded by a 


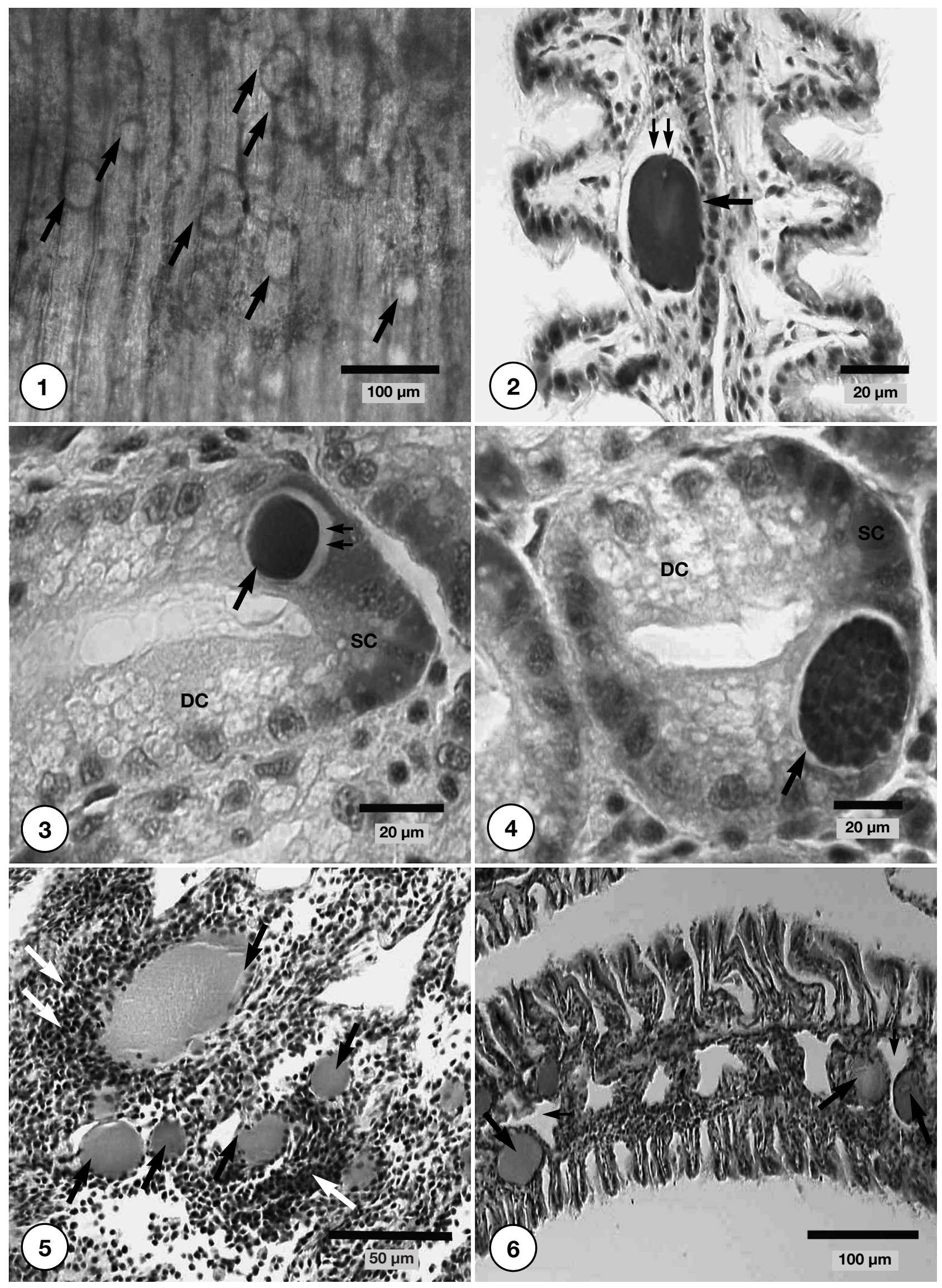


Figs. 1 to 6 . Light microscope observations of prokaryote inclusion bodies in either gill or digestive gland tissues of Dreissena sp. H\&E: hematoxylin \& eosin; SC: secretory cell; DC: digestive cell. Fig. 1. Numerous round-to-oval inclusion bodies (arrows) are visible within water-mount of freshly dissected gill filaments. Fig. 2. Paraffin section (H\&E) of gill; oval, basophilic inclusion body (arrow) in the connective tissue is surrounded by a clear zone (double arrows). Fig. 3. Paraffin section (H\&E) of digestive tubule showing round, basophilic inclusion body (arrow) surrounded by a clear zone (double arrows) in a secretory cell. Fig. 4. Paraffin section (H\&E) of digestive tubule showing coarsely granular inclusion body (arrow). Fig. 5. Paraffin section (H\&E) of heavily infected gill; the prokaryote inclusion bodies (black arrows) are surrounded by numerous infiltrated hemocytes (white arrows). Fig. 6. Paraffin section (H\&E) of heavily infected gill; inclusion bodies (large arrows) in connective tissues partially constrict water tubes (small arrows)

thick layer of fibrillar material (Fig. 8). Reticulate bodies (Figs. 7 to 9) were irregularly rounded (mean diameter $\pm \mathrm{SD}[\mathrm{n}=15]=256 \pm 60 \mathrm{~nm}$ ) and possessed an electronlucent cytoplasm, typically with peripheral condensations. Elementary bodies (Figs. 7 to 9 ) averaged ( \pm SD, $\mathrm{n}=56) 88 \pm 27 \mathrm{~nm} \times 184 \pm 30 \mathrm{~nm}$, were coccoid to fusiform (possibly reflecting cross-sectional to longitudinal sectioning, respectively), had rippled cell walls, and possessed a condensed, finely granular cytoplasm which sometimes contained electron-lucent regions. Intermediate bodies (Figs. $7 \&$ 9) had a mean diameter $( \pm \mathrm{SD}, \mathrm{n}=10)$ of $157 \pm 52 \mathrm{~nm}$. Blebs, which were expelled from reticulate bodies (Harshbarger et al. 1977), were scattered throughout the vacuoles, had a mean diameter $( \pm \mathrm{SD}, \mathrm{n}=57)$ of $50 \pm 9 \mathrm{~nm}$, and appeared irregularly rounded, thin walled, and electron-lucent (Figs. 7 to 9). In contrast to the many inclusion bodies in gill connective tissue observed histologically, none were detected in gill epithelial cells. During ultrastructural analysis, however, a small vacuole $(2.3 \times 1.5 \mu \mathrm{m})$ containing Chlamydialeslike organisms (morphologically similar to those in connective tissue cells) was noted in a single gill epithelial cell, suggesting that these tissues might on rare occasion also harbor minute infections.

\section{Digestive gland epithelial cells}

In contrast to gill tissues, inclusions in digestive gland cells were densely packed with prokaryote cells, and each inclusion exclusively contained only 1 of 4 morphological cell types (referred to here as Types I to IV). The inclusion bodies in epithelial cells that had appeared finely granular in light microscopy contained either Type I or II prokaryote cells, and those coarsely granular possessed either Type III or IV. Dimensions (mean maximum $\times$ minimum $\pm \mathrm{SD}$ ) and other characteristic features of these 4 types of prokaryote cells were:

Type I. Typically hundreds of cells per inclusion body (Fig. 10); cells (Fig. 11) relatively small, measuring $(\mathrm{n}=$ 49) $0.28 \pm 0.09 \times 0.13 \pm 0.04 \mu m_{\text {; coccoid to fusiform }}$ (possibly reflecting cross-sectional to longitudinal sectioning, respectively); cytoplasm condensed and finely granular, with numerous electron-lucent spherules; cell wall separated from plasma membrane by electron- lucent zone (presumed to be an artifact); cells occasionally surrounded by straight and curved fibrillar rods.

Type II. Typically hundreds of cells per inclusion body (Fig. 12); cells (Fig. 13) pleomorphic, measuring ( $\mathrm{n}=49$ ) $0.39 \pm 0.06 \times 0.19 \pm 0.05 \mu \mathrm{m}$; highly rippled cell wall separated from plasma membrane by electronlucent zone (presumed to be an artifact); cytoplasm condensed, finely granular, and homogeneous (without electron-lucent spherules); numerous and densely staining ribosomes at periphery; cytoplasmic or nuclear dilations occasionally observed in host cells (presumed to be an artifact); cells surrounded by large quantities of rippled fibrillar material.

Type III. Typically dozens of cells per inclusion body (Fig. 14); cells (Fig. 15) pleomorphic, but often irregularly rounded; relatively large, measuring ( $\mathrm{n}=45$ ) $0.58 \pm 0.09 \times 0.42 \pm 0.07 \mu \mathrm{m}$; cytoplasm filled with prominent ribosomes and irregular electron-lucent patches likely corresponding to fine DNA strands (as in Anderson et al. 1965); plasma membrane in close proximity to cell wall, with no electron-lucent zone separating them; cell wall flexible as evidenced by flattening due to crowding within vacuole.

Type IV. Typically dozens of cells per inclusion body (Fig. 16); cells (Fig. 17) large and irregularly rounded, measuring $(\mathrm{n}=36) 1.05 \pm 0.24 \times 0.8 \pm 0.15 \mu \mathrm{m}_{\text {; }}$ plasma membrane in close proximity to cell wall, with no electron-lucent zone separating them; cytoplasm homogeneous and without electron-lucent areas; cell wall flexible as evidenced by flattening due to crowding within vacuole; virus-like particles in cytoplasm, occasionally visible in dense paracrystalline array (Fig. 17); viruslike particles hexagonal (Fig. 18) with mean diameter (mean $\pm \mathrm{SD}, \mathrm{n}=52$ ) of $45( \pm 4) \mathrm{nm}$.

\section{DISCUSSION}

\section{Evidence of more than one prokaryote species}

The following observations, listed approximately in declining order of importance, provided evidence that the Dreissena sp. population was infected with at least 2 prokaryote species, one infecting epithelia and another connective tissues: 


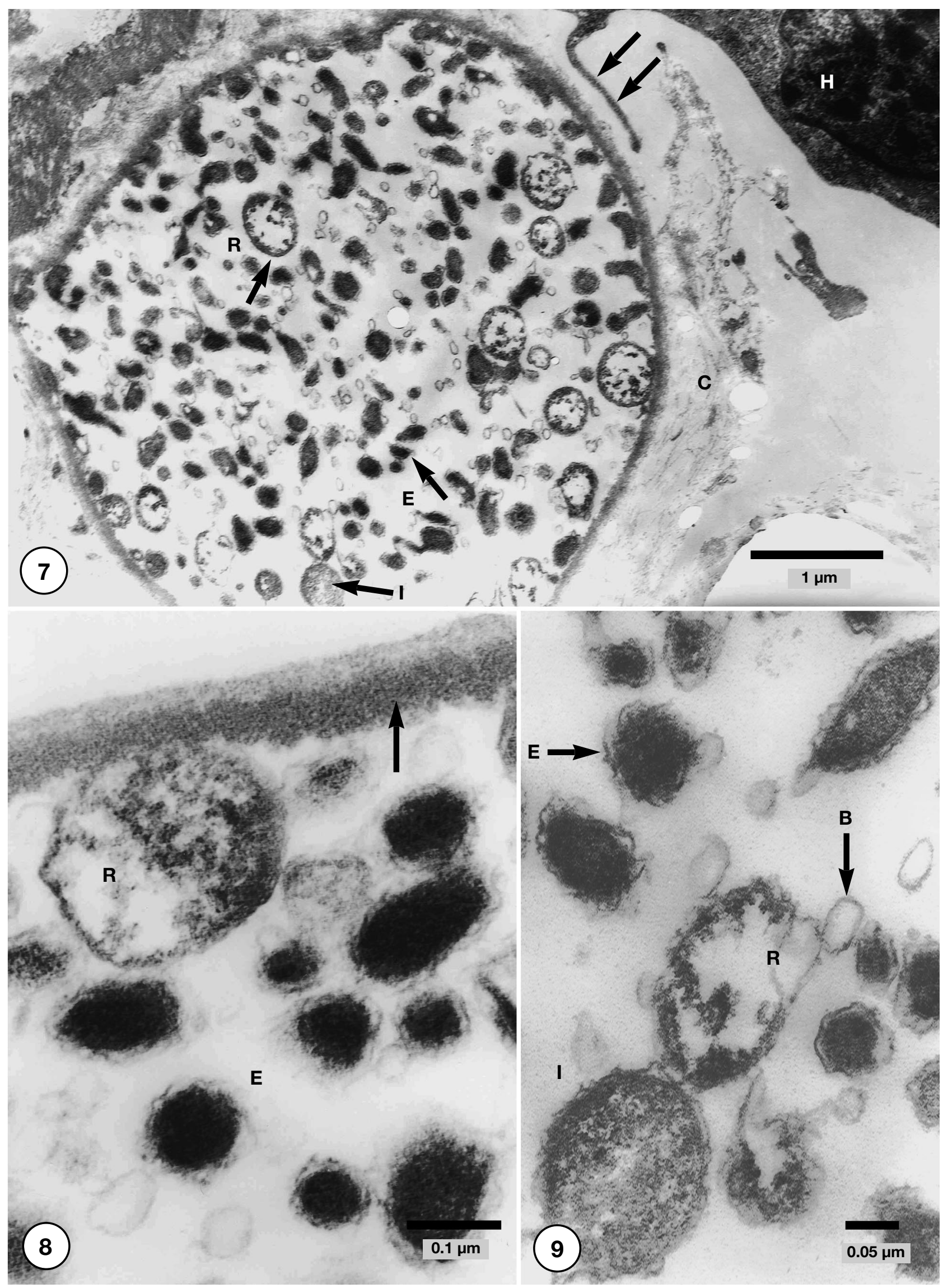


Figs. 7 to 9. Transmission electron micrographs from deparaffinized Dreissena sp. gill tissues re-embedded in resin. C: cytoplasm; H: hemocyte; R: reticulate body; I: intermediate body; E: elementary body; B: bleb. Fig. 7. Spherical vacuole containing Chlamydiales-like organisms in connective cell cytoplasm in the gill; hemocyte extending pseudopodium (double arrows) toward connective cell. Fig. 8. Details of reticulate and elementary bodies; note that the prokaryote inclusion is limited only by a thick layer of electron-dense fibrillar material (arrow). Fig. 9. Details of intermediate, reticulate, and elementary bodies; note the occurrence of blebs which presumably originate from reticulate bodies

(1) Prokaryote cell morphologies observed in the 2 types of tissues were substantially different.

(2) Based on previous studies, it would be very unusual if the same prokaryote species was present in both epithelial and connective tissues. A bivalve population with presumably the same intracytoplasmic prokaryote species in both epithelial and connective tissues has been reported only once before (Wu \& Pan 1999). Otto et al. (1979) did report intracytoplasmic infection in both tissue types in Mercenaria mercenaria, but the epithelial and connective tissues exclusively harbored different prokaryote species (i.e., chlamydial and rickettsial infections, respectively). In other reports of intracytoplasmic prokaryotes in a marine bivalve population (minimum of 38 publications, Fryer \& Lannan 1994), either epithelial or connective tissues were reported infected, never both.

(3) There was no significant correlation between the occurrence of infection in epithelial and connective tissues $(r=0.28, p=0.122$, Spearman's coefficient of rank correlation). Of the 28 mussels observed from histological sections to be infected, $78.6 \%$ had prokaryotes in only 1 tissue type (17.9\% epithelial and $60.7 \%$ connective). Moreover, when 1 tissue type was intensely infected, the other sometimes exhibited minimal to no infection; this was true for the 2 most heavily infected mussels where little to no infection was observed in their connective tissues, yet $>90$ and $>150$ inclusions per section, respectively, were present in their digestive gland epithelia.

(4) Following staining with hematoxylin and eosin, the finely granular inclusion bodies were routinely more basophilic in digestive gland epithelium than those in gill connective tissue. Otto et al. (1979) also noted a subtle difference in basophilic staining of inclusion bodies between 2 prokaryote species (rickettsial and chlamydial) observed in a population of the hard clam Mercenaria mercenaria, but in their study the reverse was true, i.e., inclusion bodies were slightly less basophilic in digestive gland epithelium than in gill connective tissue.

\section{Taxonomic assignment of prokaryotes}

Based on ultrastructural observations, the prokaryotes in gill connective tissue were clearly Chlamydiales-like (Storz \& Spears 1977). Elementary bodies and reticulate bodies were morphologically similar to the Chlamydiales-like infections reported from marine bivalves (Harshbarger et al. 1977). In contrast, the prokaryotes routinely observed in the epithelial cells were more difficult to assign taxonomically. Accurate classification of Gram-negative, intracellular prokaryotes based on morphology observed by light and electron microscopy can be difficult (Fryer \& Lannan 1994), including these epithelial prokaryotes. Their cell pleomorphism, trilaminar cell wall and plasmalemma, and internal bacterium-like organization indicated that they were either in the order Rickettsiales or Chlamydiales, but unfortunately there is no histological stain to unequivocally distinguish between these 2 prokaryote orders. Thus, the results of the Giemsa (i.e., colonies blue) and Ordway-Macchiavello (i.e., colonies red) staining performed herein only confirmed that the prokaryotes might be in either order. Although 4 morphological types of cells were observed, a mixture of cell types resembling electron-lucent reticulate bodies and elementary bodies was never observed within any inclusion body. By default, these prokaryotes must be considered Rickettsiales-like.

\section{Infection prevalence}

As would be expected due to the small size of cytoplasmic inclusion bodies, overall prokaryote infection intensity as determined from dissection data (17.0\%) was substantially less than indicated by histological analysis $(87.5 \%)$. Considering that typically only 4 sections per mussel were examined, it is highly likely that even histological analysis underestimated true infection prevalence. A wide range of prevalences with intracytoplasmic prokaryotes occur in marine bivalves, including similar extensive infections, e.g., ca $100 \%$ by both Gulka \& Chang (1984) and Le Gall et al. (1991), >85\% by Johnson \& Le Pennec (1995), and $\leq 75 \%$ by Buchanan (1978).

During dissections, inclusion bodies were observed in the gills (Fig. 1) of $28.6 \%(42 / 147)$ of the mussels $\geq 10 \mathrm{~mm}$ in length versus $0 \%(0 / 100)$ in smaller mussels (Table 1). This does not indicate that mussels $<10 \mathrm{~mm}$ in length were uninfected. In their histological study, Norton et al. (1993) recorded smaller inclusions in juvenile than in adult giant clams. Thus, the inability to 


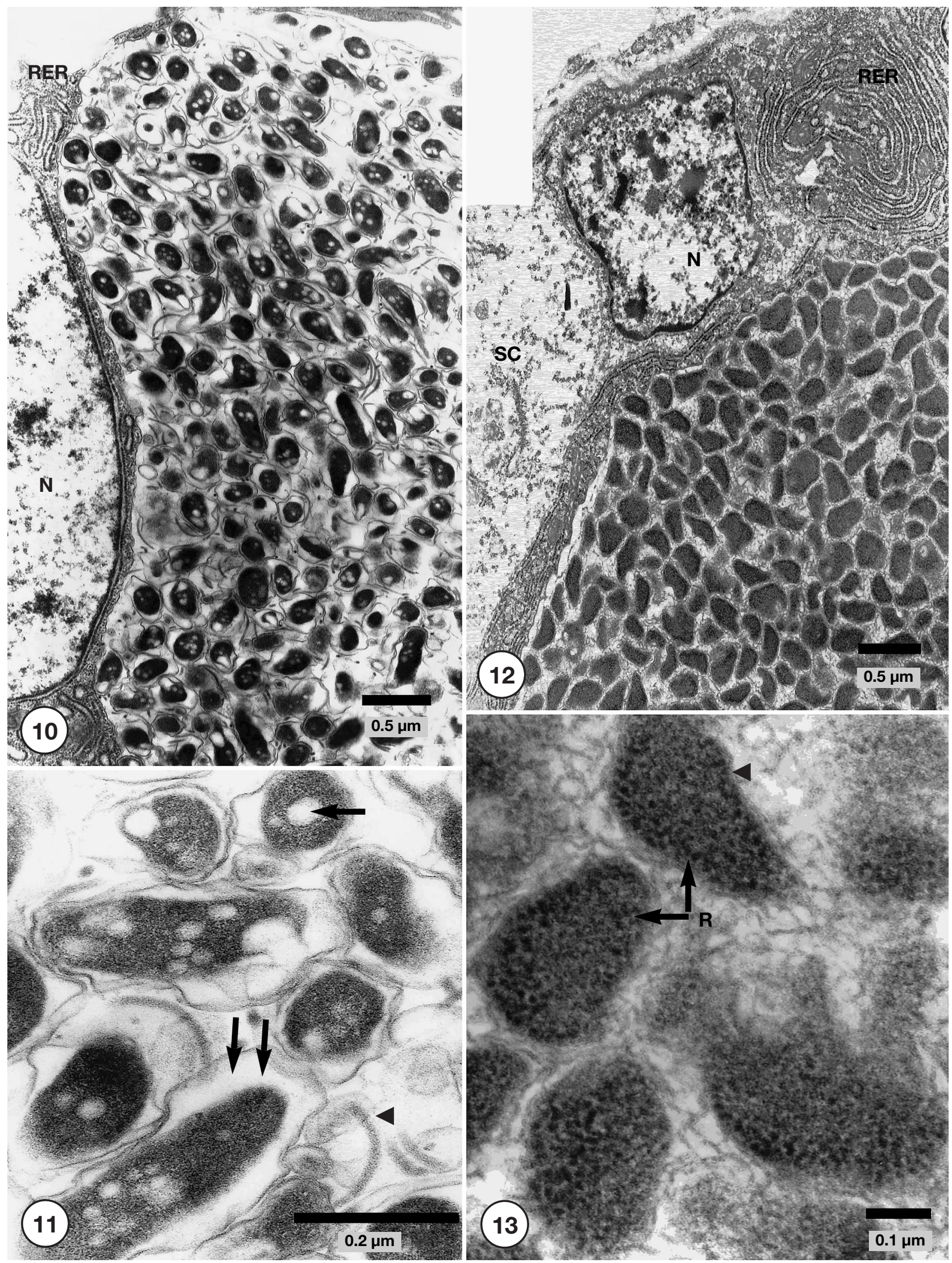


Figs. 10 to 13. Transmission electron micrographs of Type I and II prokaryotes from deparaffinized Dreissena sp. digestive gland tissues re-embedded in resin. RER: rough endoplasmic reticulum; N: nucleus; SC: secretory cell; R: ribosomes. Fig. 10. Intracytoplasmic inclusion body containing numerous coccoid to fusiform Type I prokaryotes in a secretory cell of a digestive gland tubule. Fig. 11. Details of Type I prokaryote cells with condensed cytoplasm and numerous electron-lucent spherules (arrow); the cell wall often separated from the plasma membrane and presumed to be an artifact (double arrows); fibrillar rods (arrowhead) occasionally visible among Type I prokaryote cells. Fig. 12. Intracytoplasmic inclusion body containing numerous pleomorphic prokaryote organisms typical of Type II found in a secretory cell of a digestive gland tubule. Fig. 13. Details of prokaryote cells of Type II with rippled cell wall (arrowhead) and condensed cytoplasm containing numerous ribosomes; note that the cells are surrounded by rippled fibrillar material

detect infection in juvenile Dreissena sp. during dissection could well have been the result of inclusion bodies being too small to detect at $\leq 70 \times$. Among the Dreissena sp. chosen for histological analysis, size was not recorded during sectioning, and thus further histological studies will be needed to confirm that mussels $<10 \mathrm{~mm}$ in length can also harbor infection.

\section{Epithelial infection}

Colonies within epithelial cells were frequently in close contact with rough endoplasmic reticulum, and it was not possible to clearly demonstrate whether they were host membrane-limited (Figs. 10, 12, 14 \& 19). We observed intracytoplasmic prokaryotes in both digestive and secretory cells of the digestive gland epithelium. This is unusual since such infections in the digestive gland of marine bivalve populations have been almost always limited to either the digestive (Meyers 1979, Elston \& Peacock 1984, Robledo et al. 1994) or secretory cells (Buchanan 1978, Comps \& Raimbault 1978, Comps 1983). The only exception we are aware of is a population of the littoral bivalve Loripes lucinalis in Brest, France, in which both digestive gland cell types were observed infected (Herry et al. 1994, Johnson \& Le Pennec 1995).

We suspect that several artifacts were likely present in the electron micrographs. These included the electron-lucent zone separating the cell wall from plasma membrane in Type I and II prokaryotes and the cytoplasmic or nuclear dilations occasionally observed in host cells infected with Type II prokaryotes.

\section{Connective tissue infection}

Our observation of intracytoplasmic prokaryotes in connective tissues represents only the third such report in bivalves. Renault \& Cochennec (1995) recorded a chlamydia-like infection in the connective tissue cytoplasm of the gills and mantle of Japanese oysters. In a study of the hard clam Mercenaria mercenaria, Otto et al. (1979) found rickettsiae-like organisms most frequently in gill connective tissues. In our study, not only were gills the organ most likely to have infected connective tissue, but also the organ whose connective tissues harbored the largest colonies. Our observation of infection in connective tissue within the gonads of a single male mussel contrasted with the only other report of an intracytoplasmic prokaryote in bivalve gonads (Fries \& Grant 1991) in which colonies were observed directly within ova.

\section{Inclusion bodies}

This is the first reported observation of prokaryote inclusion bodies in bivalves during dissection (Fig. 1). Gross indentations in the gills of Pacific oysters resulting from tissue destruction by chlamydia-like organisms have been reported (Renault \& Cochennec 1995), but the prokaryote inclusion bodies themselves were too small for gross observation. Tumorlike lesions, considered the result of traumatic irritation or infection with rod-shaped bacteria, were observed in the mantle and gills of Dreissena polymorpha by Morton (1974). He reported that, in extreme cases, lesions developed into granulomas which could be freely dissected out and were usually quite hard, creamy white in color, and 1 to $2 \mathrm{~mm}$ in diameter. Histologically, these lesions bear no resemblance to the intracytoplasmic prokaryote infections reported herein.

As in the present study, cytoplasmic inclusion bodies containing prokaryote colonies in marine bivalves have usually been reported to be larger in gill tissues, e.g., $\leq 45 \mu \mathrm{m}$ in Gulka et al. (1983), $\leq 55 \mu \mathrm{m}$ in Elston (1986a), $\leq 230 \mu \mathrm{m}$ in Goggin \& Lester (1990), $\leq 110 \mu \mathrm{m}$ in Norton et al. (1993), $\leq 90 \mu \mathrm{m}$ in Wen et al. (1994), $\leq 30 \mu \mathrm{m}$ in Johnson \& Le Pennec (1995), than in the digestive gland cells, e.g., $\leq 12 \mu \mathrm{m}$ in Comps \& Raimbault (1978), $\leq 25 \mu \mathrm{m}$ in Comps (1982), $\leq 13.5 \mu \mathrm{m}$ in Elston \& Peacock (1984), $\leq 15 \mu \mathrm{m}$ in Cajaraville \& Angulo (1991), $\leq 22 \mu \mathrm{m}$ in Wen et al. (1994), $\leq 10 \mu \mathrm{m}$ in Comps \& Tigé (1999). Our observation of gill prokaryote inclusion bodies of up to $138 \mu \mathrm{m}$, one of the largest reported from bivalves, was likely related to our standard protocol of inspecting large areas of gill surface with the dissection microscope. Bivalve investigations have traditionally relied on detecting inclusion bodies from the relatively limited 


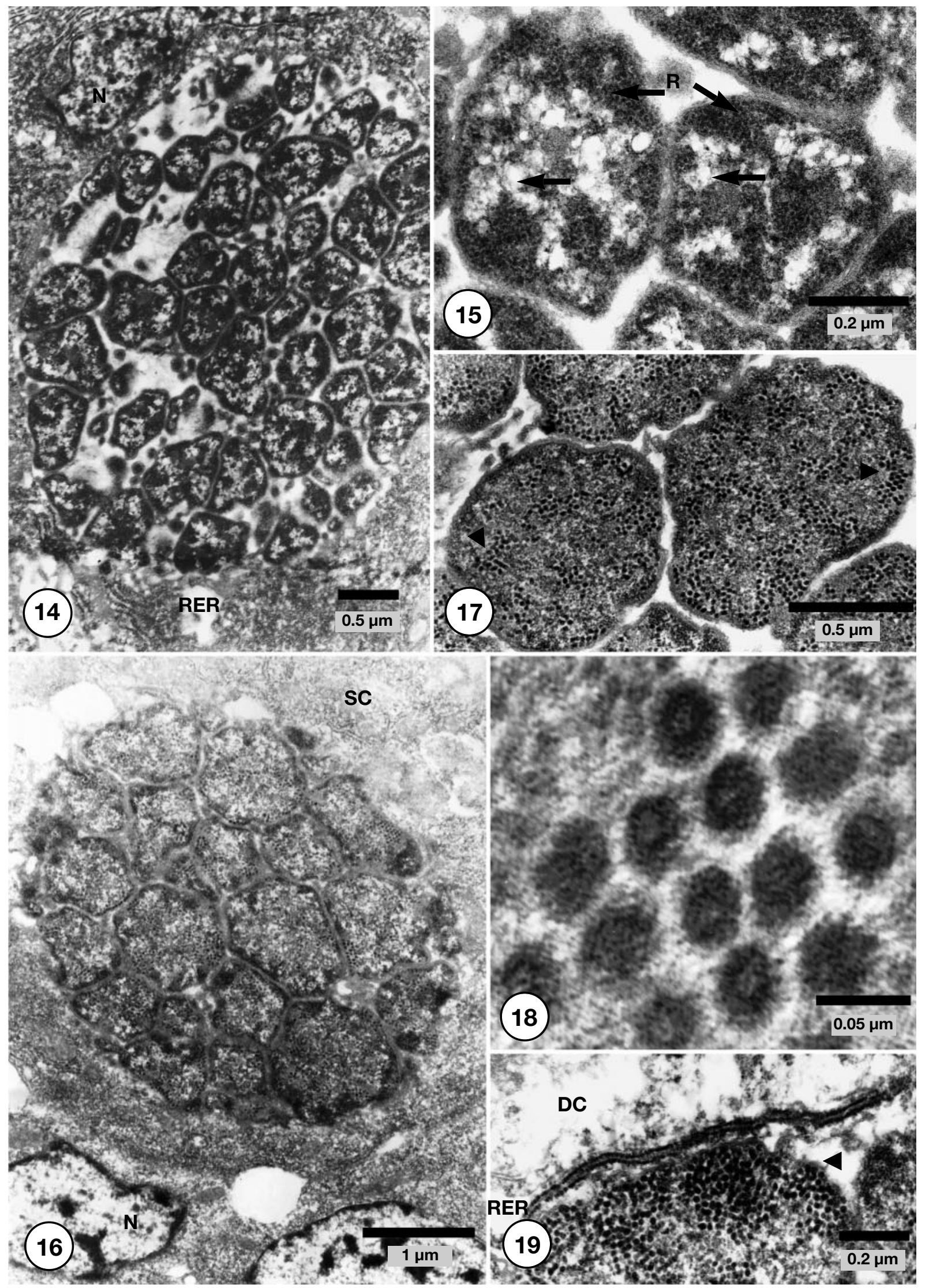


Figs. 14 to 19. Transmission electron micrographs of Type III and IV prokaryotes from deparaffinized Dreissena sp. digestive tissues re-embedded in resin. RER: rough endoplasmic reticulum; N: nucleus; R: ribosomes; SC: secretory cell; DC: digestive cell. Fig. 14. Intracytoplasmic inclusion body containing irregularly rounded prokaryote organisms typical of Type III found in a secre-

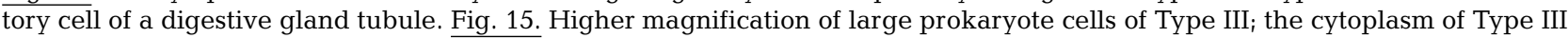
prokaryotes contains ribosomes and electron-lucent patches corresponding to DNA strands (arrows). Fig. 16. Intracytoplasmic inclusion body containing large rounded prokaryote organisms typical of Type IV found in a secretory cell of a digestive gland tubule. Fig. 17. Details of large Type IV prokaryote cells containing virus-like particles occasionally occurring in paracrystalline array (arrowheads). Fig. 18. Higher magnification of hexagonal virus-like particles in paracrystalline array each with a clear central zone occurring in the cytoplasm of Type IV prokaryote cells. Fig. 19. High magnification of the peripheral zone of an inclusion containing Type IV prokaryote cells (arrowhead) and their virus-like particles; note the single tubule of rough endoplasmic reticulum in the cytoplasm of this digestive cell and that no membrane apparently separates it from the prokaryote cells

material provided by serial sections. If we had relied on histological material alone, we would have reported a maximum inclusion body size of only $75 \mu \mathrm{m}$.

The clear zones sometimes observed surrounding inclusion bodies (Figs. $2 \& 3$ ) were not likely related to host-parasite interactions. We did not observe these clear zones in our TEM observations, and thus they were probably an artifact of histological processing. Similar clear zones have also been present in paraffin sections of prokaryote infections in marine bivalves (Comps et al. 1977, Buchanan 1978).

\section{Virus-like particles}

The presence of virus-like particles in electron-dense paracrystalline arrays within intracytoplasmic prokaryotes has been reported in marine bivalves, all from infections within digestive gland epithelium. Records of such hyperparasitism include both Rickettsiales-like (Buchanan 1978, Wen et al. 1994, Comps \& Tigé 1999) and Chlamydiales-like organisms (Harshbarger et al. 1977, Meyers 1979, Johnson \& Le Pennec 1995). These reports also noted that prokaryote cells containing such virus-like particles, like our Type IV cells, were larger than uninfected cells and were likely a terminal phase in the prokaryote's life cycle, with host cells eventually lysing. Mean diameters of these virus-like particles in bivalves have ranged from $41 \mathrm{~nm}$ (Wen et al. 1994) to $67 \mathrm{~nm}$ (Buchanan 1978), and thus the virus-like particles we observed (mean diameter, $45 \mathrm{~mm}$ ) were relatively small and similar in size to those observed by Comps \& Tigé (1999) in Mytilus galloprovincialis. Each particle had a hexagonal outline (Fig. 18) similar to virus-like particles within prokaryotes in the intertidal bivalve Tellina tenuis (Buchanan 1978).

\section{Host pathology}

Infection was fairly benign in Dreissena sp. Although individual infected epithelial cells appeared to suffer cytopathic effects in the digestive gland, the epithe- lium in general did not appear damaged, even when infection intensity was high. The cycle of shedding and regeneration of digestive gland epithelium in bivalves likely serves to minimize the impact of such prokaryote infections. Although it is the likely course of events in nature, there was no direct evidence of the breakdown of host cell membranes and release of prokaryotes as observed for other bivalve intracytoplasmic prokaryotes in cells within the gill (Fries \& Grant 1991, Villalba et al. 1999) and digestive gland (Meyers 1979, Herry et al. 1994, Wen et al. 1994). Although infection prevalence was very high (ca $\geq 87.5 \%$ ), no major, adverse impact on body condition was evident among the 32 Dreissena sp. sectioned or 247 dissected. Host response was clear, however, from dense hemocyte infiltration into infected tissues (Fig. 5). The most apparent adverse effect of infection was partial constriction of gill water tubes (Fig. 6). At the densities of inclusion bodies observed, however, significant interference with respiration and other metabolic functions of the gills was highly unlikely. A similar conclusion was reached in a study of intracytoplasmic prokaryote infection in gills of a marine bivalve (Renault \& Cochennec 1994). In the only report of intranuclear infection by prokaryote-like organisms in bivalves, Elston (1986b) observed occlusion of gill water tubes in the Pacific razor clam Siliqua patula in association with massive mortalities. In heavy infections, tubes were blocked by the release of nuclei infected with these microorganisms as well as by epithelial cell hypertrophy.

Other than mild cytopathic effects, marine bivalve investigations, however, have typically recorded no significant, detrimental effects on hosts from intracytoplasmic prokaryote infections. Although, intracytoplasmic prokaryote infections have occasionally been associated with mass mortalities of marine bivalves in Europe (Le Gall et al. 1991, Villalba et al. 1999), North America (Gulka et al. 1983), and Asia (Wu \& Pan 1999), studies to date (Gulka \& Chang 1984) have yet to definitively demonstrate that the prokaryotes per se were the primary lethal etiological agents. Norton et al. (1993), for example, suggested that al- 
though Rickettsiales-like organisms were common in gill epithelium of dying giant clams Hippopus hippopus, stress from rearing conditions may have been largely responsible for the mortalities. Stress due to concurrent trematode infection was also considered to be the most probable cause for expression of a Rickettsiales-like infection in a freshwater snail (Adam et al. 1994). Although Elston (1986b) presented evidence of a link between intranuclear prokaryote-like infection and razor clam mortalities, he indicated that his morphological study could not be used to conclusively establish cause and effect. One of the most convincing records of bivalve mortality directly due to intracytoplasmic prokaryotes was a Chlamydiales infection in hatchery-reared larval (ca 80 to $100 \%$ mortality) and postmetamorphic (ca 40 to $60 \%$ mortality) bay scallops in which infection was associated with the complete destruction of their digestive tract epithelial lining; the prevalence and importance of this disease for wild larval and postmetamorphic stocks of scallops, however, remains unknown (Leibovitz 1989).

Although there may be no definitive, experimental evidence that prokaryote infections in bivalves can induce lethality, the symbiotic relationship of these intracytoplasmic prokaryotes to their hosts, including Dreissena, is still generally considered parasitic. In support of this, Le Gall et al. (1991) provided evidence of energetic loss due to rickettsial infection in Pecten maximus. In their study of the effect of a Chlamydialike prokaryote in Crassostrea gigas, Soletchnik et al. (1998) demonstrated that clearance rates were positively correlated with gill abnormalities and suggested that this compensated for the loss in gill surface function. In contrast, Johnson \& Le Pennec (1995) have suggested that Chlamydiales-like prokaryotes in the littoral clam Loripes lucinalis could be a beneficial symbiont. They speculated that host clams might systemically benefit by obtaining some essential nutrients such as fatty acids or vitamins via prokaryote colony digestion, and the specialized gill bacteriocyte cells of these clams might directly benefit by phagocytosis of prokaryotes.

\section{Research imbalance}

This is the first report of intracytoplasmic prokaryote organisms from a freshwater bivalve. In contrast, at least 39 primary research papers (see Fryer \& Lannan 1994) have been published over the last 20 years reporting on intracytoplasmic prokaryote infections in at least 25 marine bivalve species (e.g., oysters, scallops, clams, and mussels). This freshwater versus marine publication imbalance is almost certainly the result of the relative lack of parasitological studies of fresh- water bivalves - a group of no major commercial importance. Bivalve pathology has traditionally been an applied science funded in large part to understand and minimize diseases of commercially valuable species. The present paper actually follows in this tradition, but with a twist. The fundamental research reported herein emerged out of a need to understand and possibly maximize diseases of a commercially harmful species.

\section{Future research}

Could intracytoplasmic prokaryotes in Dreissena and other molluscs be of wider ecological importance? Currently, the life cycles of none of the intracytoplasmic prokaryotes in marine bivalves have been clearly elucidated. Do bivalves serve as reservoir hosts in complex prokaryote life histories or are these diseases exclusively cycling in bivalve hosts? Intracytoplasmic prokaryotes in vertebrates are typically known to have complex life cycles involving obligate, alternate hosts. The question of what role freshwater bivalves may play as alternate hosts or reservoirs for the spread of vertebrate rickettsial or chlamydial diseases was first raised by Harshbarger et al. (1977). Buchanan (1978) did have limited success in culturing an intracellular prokaryote from a marine intertidal bivalve in hens' eggs, and this provided some evidence that such prokaryotes might truly have an alternate host in birds, but no other similar studies have been reported since. The recent detection of the rickettsial species Ehrlichia risticii, the agent of Potomac horse fever, in freshwater stream snails near pastures where this equine disease was enzootic (Barlough et al. 1998, Reubel et al. 1998) may rekindle interest in examining bivalve-vertebrate transmission theories. It appears, however, that some prokaryotes can cycle for at least part of their life history in their bivalve hosts since horizontal transinfection of Rickettsiales infection in scallops has been successfully achieved in the laboratory (Gulka \& Chang 1984, Le Gall et al. 1991). Such intraspecific, horizontal, transinfection trials are thus a logical next step with Dreissena's prokaryotes. If successful, then transinfection could provide a continuous laboratory supply of prokaryotes for determining other key research goals such as taxonomic clarification, life cycle, host specificity, and life stage susceptibility. Because intracytoplasmic prokaryotes infecting bay scallops are particularly pathogenic to their larval and postmetamorphic stages (Leibovitz 1989), transmission trials focusing on Dreissena's larval and juvenile stages could reveal a level of pathogenicity not evident in the current study.

In such future research efforts, techniques already developed in marine studies could be useful. The protocols of Le Gall \& Mialhe (1992) could be adapted for 
purifying prokaryotes from infected zebra mussel tissues. A highly sensitive and specific diagnostic DNAbased probe (Kellner-Cousin et al. 1993) could serve as a practical tool for detection and quantification of Dreissena's prokaryotes. Efforts to clarify the taxonomic position of Dreissena's prokaryotes could specifically make use of techniques such as antigenic structure determination (Renault \& Cochennec 1995), protein electrophoresis (Le Gall \& Mialhe 1992), and analysis of genomic content (e.g., 16S, internal transcribed spacer, and 23S ribosomal DNA sequencing, Mauel et al. 1999).

Acknowledgements. This research was funded by grants from the U.S. Army Engineers Waterways Experiment Station Zebra Mussel Research Program (to D.P.M.) and the National Science Foundation Division of International Programs (to Robert E. Baier and D.P.M.). We especially thank Estelle Labeyrie, Marie-Anne Pruniéres, and Jean-Robert Bonami for their help in setting up the temporary laboratory in Seillans (France), Marilena Zarfdjian for fieldwork, Tristan Renault and John Fryer for manuscript review, and Robert Lutringer for statistical advice. The assistance of the following IRCOMS colleagues during mussel dissection is gratefully acknowledged: Lyubov Burlakova, Alexander Karatayev, Dina Kurandina, Peter Mitrakhovich, Mykola Ovcharenko, Victor Prostokvashin, and Vitali Roitman. Preparation of the manuscript was supported in part by travel grants from the Université de Metz (to D.P.M. and L.G.). Many thanks as always to the staff of the New York State Library for generously assisting in obtaining scientific literature.

\section{LITERATURE CITED}

Adam R, Pipitgool V, Sithithaworn P, Hinz E, Storch V (1994) Rickettsiales-like organisms in the digestive gland of Bithynia siamensis goniomphalus (Prosobranchia: Bithyniidae) infected with Opisthorchis viverrini (Trematoda: Digenea). J Invertebr Pathol 63:26-30

Anderson DR, Hopps HE, Barile MF, Bernheim BC (1965) Comparison of the ultrastructure of several rickettsiae, ornithosis virus and Mycoplasma in tissue culture. J Bacteriol 90:1387-1404

Barlough JE, Reubel GH, Madigan JE, Vredevoe LA, Miller PE, Rikihisa Y (1998) Detection of Ehrlichia risticii, the agent of Potomac horse fever, in freshwater stream snails (Pleuroceridae: Juga spp.) from northern California. Appl Environ Microbiol 64:2888-2893

Bower SM, McGladdery SE, Price IM (1994) Synopsis of infectious diseases and parasites of commercially exploited shellfish. Annu Rev Fish Dis 4:1-199

Buchanan JS (1978) Cytological studies on a new species of rickettsia found in association with a phage in the digestive gland of the marine bivalve mollusc, Tellina tenuis (da Costa). J Fish Dis 1:27-43

Burlakova LE, Karatayev AY, Molloy DP (1998) Field and laboratory studies of zebra mussel (Dreissena polymorpha) infection by the ciliate Conchophthirus acuminatus in the Republic of Belarus. J Invertebr Pathol 71:251-257

Cajaraville MP, Angulo E (1991) Chlamydia-like organisms in digestive and duct cells of mussels from the Basque coast. J Invertebr Pathol 58:381-386
Camp JW, Blaney LM, Barnes DK (1999) Helminths of the round goby, Neogobius melanostomus (Perciformes: Gobiidae), from southern Lake Michigan, Indiana. J Helminthol Soc Wash 66:70-72

Comps M (1982) Etude morphologique d'une infection rickettsienne de la palourde Ruditapes philippinarum Adam and Reeves. Rev Trav Inst Pêches Marit 44(1983):277-283

Comps M (1983) Infections rickettsiennes chez les mollusques bivalves des côtes françaises. Rapp P V Reun Cons Int Explor Mer 182:134-136

Comps M, Raimbault R (1978) Infection rickettsienne de la glande digestive de Donax trunculus Linné. Sci Peche Bull Inst Pêches Marit 281:11-12

Comps M, Tigé G (1999) Procaryotic infections in the mussel Mytilus galloprovincialis and in its parasite the turbellarian Urastoma cyprinae. Dis Aquat Org 38:211-217

Comps M, Bonami JR, Vago C (1977) Mise en évidence d'une infection rickettsienne chez les huîtres. C R Hebd Seances Acad Sci Ser D Sci Nat 285:427-429

Elston RA (1986a) Occurrence of branchial rickettsiales-like infection in two bivalve molluscs, Tapes japonica and Patinopecten yessoensis, with comments on their significance. J Fish Dis 9:69-71

Elston RA (1986b) An intranuclear pathogen [nuclear inclusion X (NIX)] associated with massive mortalities of the Pacific razor clam, Siliqua patula. J Invertebr Pathol 47: 93-104

Elston RA, Peacock MG (1984) A rickettsiales-like infection in the Pacific razor clam, Siliqua patula. J Invertebr Pathol 44:84-96

Fahnenstiel GL, Bridgeman TB, Lang GA, McCormick MJ, Nalepa TF (1995) Phytoplankton productivity in Saginaw Bay, Lake Huron: effects of zebra mussel (Dreissena polymorpha) colonization. J Gt Lakes Res 21:465-475

Fries CR, Grant DM (1991) Rickettsiae in gill epithelial cells of the hard clam, Mercenaria mercenaria. J Invertebr Pathol 57:166-171

Fryer JL, Lannan CN (1994) Rickettsial and chlamydial infections of freshwater and marine fishes, bivalves, and crustaceans. Zool Stud 33:95-107

Goggin GL, Lester RJG (1990) Rickettsiales-like infection in the gills of Tridacna crocea from the Great Barrier Reef. J Invertebr Pathol 56:135-138

Gulka G, Chang PW (1984) Pathogenicity and infectivity of a rickettsia-like organism in the sea scallop, Placopecten magellanicus. J Fish Dis 8:309-318

Gulka G, Chang PW, Marti KA (1983) Prokaryotic infection associated with a mass mortality of the sea scallop Placopecten magellanicus. J Fish Dis 6:355-364

Harshbarger JC, Chang SC, Otto SV (1977) Chlamydiae (with phages), mycoplasmas, and rickettsiae in Chesapeake Bay bivalves. Science (Wash DC) 196:666-668

Herry A, Le Pennec M, Johnson M (1994) Bacteria-host relationships in the bivalve mollusc Loripes lucinalis. Acta Microbiol Immunol Hung 41:273-281

Humason GL (1979) Animal tissue techniques, 4th edn. WH Freeman and Co, San Francisco

Johnson MA, Le Pennec M (1995) Association between the mollusc bivalve Loripes lucinalis and a Chlamydia-like organism, with comments on its pathogenic impact, life cycle and possible mode of transmission. Mar Biol 123: 523-530

Karatayev AY, Burlakova LE, Padilla DK (1997) The effects of Dreissena polymorpha (Pallas) invasion on aquatic communities in eastern Europe. J Shellfish Res 16: $187-203$

Karatayev AY, Burlakova LE, Molloy DP, Volkova LK (2000a) 
Endosymbionts of Dreissena polymorpha (Pallas) in Belarus. Int J Hydrobiol 85:543-559

Karatayev AY, Molloy DP, Burlakova LE (2000b) Seasonal dynamics of Conchophthirus acuminatus (Ciliophora, Conchophthiridae) infection in Dreissena polymorpha and D. bugensis (Bivalvia, Dreissenidae). Eur J Protistol (in press)

Kellner-Cousin K, Le Gall G, Despres B, Kaghad M, Legoux P, Shire D, Mialhe E (1993) Genomic DNA cloning of rickettsia-like organisms (RLO) of Saint-Jacques scallop Pecten maximus: evaluation of prokaryote diagnosis by hybridization with a non-isotopically labelled probe and by polymerase chain reaction. Dis Aquat Org 15:145-152

Laruelle F, Molloy DP, Fokin SI, Ovcharenko MA (1999) Histological analysis of mantle-cavity ciliates in Dreissena polymorpha: their location, symbiotic relationship, and distinguishing morphological characteristics. J Shellfish Res 18:251-257

Laruelle F, Molloy DP, Roitman VA (2001) Histological analysis of trematodes in Dreissena polymorpha: their location, pathogenicity, and distinguishing morphological characteristics. J Parasitol (in press)

Le Gall G, Mialhe E (1992) Purification of Rickettsiales-like organisms associated with Pecten maximus (Mollusca: Bivalvia): serological and biochemical characterization. Dis Aquat Org 12:215-220

Le Gall G, Mialhe E, Chagot D, Grizel H (1991) Epizootiological study of rickettsiosis of the Saint Jacques scallop Pecten maximum. Dis Aquat Org 10:139-145

Leibovitz L (1989) Chlamydiosis: a newly reported serious disease of larval and postmetamorphic bay scallops, Argopecten irradians (Lamarck). J Fish Dis 12:125-136

Mauel MJ, Giovannoni SJ, Fryer JL (1999) Phylogenetic analysis of Piscirickettsia salmonis by $16 \mathrm{~S}$, internal transcribed spacer (ITS) and 23S ribosomal DNA sequencing. Dis Aquat Org 35:115-123

Meyers TR (1979) Preliminary studies on a chlamydial agent in the digestive diverticular epithelium of hard clams Mercenaria mercenaria (L.) from Great South Bay, New York. J Fish Dis 2:179-189

Meyers TR (1981) Endemic diseases of cultured shellfish of Long Island, New York: adult and juvenile American oysters (Crassostrea virginica) and hard clams (Mercenaria mercenaria). Aquaculture 22:305-330

Molloy DP (1998) The potential for using biological control technologies in the management of Dreissena spp. J Shellfish Res 17:177-183

Molloy DP, Roitman VA, Shields JD (1996) Survey of the parasites of zebra mussels (Bivalvia: Dreissenidae) in northwestern Russia, with comments on records of parasitism in Europe and North America. J Helminthol Soc Wash 63:251-256

Molloy DP, Karatayev AY, Burlakova LE, Kurandina DP, Laruelle F (1997) Natural enemies of zebra mussels: predators, parasites, and ecological competitors. Rev Fish Sci 5:27-97

Morton B (1974) Studies on the biology of Dreissena polymorpha. VI. The occurrence of chronic pallial and ctenidial inflammatory granulomas - the response to injury. J Invertebr Pathol 23:106-113

Norton JH, Shepherd MA, Abdon-Naguit MR, Lindsay S (1993) Mortalities in the giant clam Hippopus hippopus

Editorial responsibility: Albert Sparks,

Seattle, Washington, USA associated with Rickettsiales-like organisms. J Invertebr Pathol 62:207-209

O'Neill CR Jr (1996) The zebra mussel: impacts and control. Cornell Coop Ext Inf Bull 238:1-62

O'Neill CR Jr (1997) Economic impact of zebra musselsresults of the 1995 National Zebra Mussel Information Clearinghouse study. Gt Lakes Res Rev 3:35-44

Otto SV, Harshbarger JC, Chang SC (1979) Status of selected unicellular eucaryote pathogens, and prevalence and histopathology of inclusions containing obligate procaryote parasites, in commercial bivalve mollusks from Maryland estuaries. Haliotis 8(1977):285-295

Renault T, Cochennec N (1994) Rickettsia-like organisms in the cytoplasm of gill epithelial cells of the Pacific oyster Crassostrea gigas. J Invertebr Pathol 64:160-162

Renault T, Cochennec N (1995) Chlamydia-like organisms in ctenidia and mantle cells of the Japanese oyster Crassostrea gigas from the French Atlantic coast. Dis Aquat Org 23:153-159

Reubel GH, Barlough JE, Madigan JE (1998) Production and characterization of Ehrlichia risticii, the agent of Potomac horse fever, from snails (Pleuroceridae: Juga spp.) in aquarium culture and genetic comparison to equine strains. J Clin Microbiol 36:1501-1511

Robledo JAF, Santarém MM, Figueras A (1994) Parasite loads of rafted blue mussels (Mytilus galloprovincialis) in Spain with special reference to the copepod, Mytilicola intestinalis. Aquaculture 127:287-302

Schloesser DW, Nalepa TF, Mackie GL (1996) Zebra mussel infestation of unionid bivalves (Unionidae) in North America. Am Zool 36:300-310

Soletchnik P, Goulletquer P, Cochennec N, Renault T, Geairon P (1998) Ecophysiological study of the Pacific oyster Crassostrea gigas naturally infected by a Chlamydia-like microorganism: effect of infection level and diet on oyster physiological responses. Haliotis 27:1-19

Stewart TW, Miner JG, Lowe, RL (1998) Quantifying mechanisms for zebra mussel effects on benthic macroinvertebrates: organic matter production and shell-generated habitat. J N Am Benthol Soc 17:81-94

Storz J, Spears P (1977) Chlamydiales: properties, cycle of development and effect on eukaryotic host cells. Curr Top Microbiol Immunol 76:167-214

Strayer DL (1999) Effects of alien species on freshwater mollusks in North America. J N Am Benthol Soc 18:74-98

Toews S, Beverly-Burton M, Lawrimore T (1993) Helminth and protist parasites of zebra mussels, Dreissena polymorpha (Pallas, 1771), in the Great Lakes region of southwestern Ontario, with comments on associated bacteria. Can J Zool 71:1763-1766

Villalba A, Carballal MJ, Lopez C, Cabada A, Corral L, Azevedo C (1999) Branchial rickettsia-like infection associated with clam Venerupis rhomboides mortality. Dis Aquat Org 36:53-60

Wen CM, Kou GH, Chen SN (1994) Rickettsiaceae-like microorganisms in the gill and digestive gland of the hard clam, Meretrix lusoria Röding. J Invertebr Pathol 64: 138-142

Wu X, Pan J (1999) Studies on rickettsia-like organism disease of the tropical marine pearl oyster. I. The fine structure and morphogenesis of Pinctada maxima pathogen rickettsia-like organism. J Invertebr Pathol 73:162-172

Submitted: May 16, 2000; Accepted: November 3, 2000

Proofs received from author(s): March 13, 2001 